\title{
Behavior Analysis of Legislators in Health Planning in South Sulawesi Province
}

\author{
Indar $^{1, *}$, Muhammad Alwy Arifin ${ }^{1}$, Nurhayani $^{1}$ and Anwar Mallongi ${ }^{2}$ \\ ${ }^{1}$ Department of Health Administration and Policy, Faculty of Public Health, Hasanuddin University, Indonesia \\ ${ }^{2}$ Department of Environmental Health, Faculty of Public Health, Hasanuddin University, Indonesia
}

\begin{abstract}
Health is political because its social determinants are easily accepted in political intervention. Therefore, the health system of a region mandates that health development will take place well if it is supported by good and targeted planning. The purpose of this study is to analyze the behavior of legislators in planning health services in South Sulawesi Province. The research was conducted in the DPRD of Makassar City and Bantaeng Regency. This type of research is a qualitative research. Data was collected using in-depth interviews, observation and document review. Data processing was carried out using triangulation and content analysis methods. The results showed that based on indicators of knowledge, attitudes, perceptions and actions of legislators were in the poor category. In addition, it was known that there was an interest from legislators in terms of health planning, but this interest was indirectly in the interest of improving public health status.
\end{abstract}

Keywords: Attitudes, Behavior, Education, Legislators, Perception, Planning.

\section{INTRODUCTION}

Health is politics because of its social determinants (Social Determinants) are easily accepted in political interventions, depending on political actions (health determinants) and activities that aims to increase health needs through organized community efforts. Therefore, the health system of an area mandates that health development will take place well if it is supported by good and targeted planning (Pallutturi, 2015).

The development planning and budgeting process is a cycle, which has been regulated in a planning mechanism regulation. This cycle starts from the assessment of the current situation to the preparation of action plans and budgets both at the national and regional levels. Speaking at the regional level, based on Government Regulation (PP) No. 08 of 2008 concerning Stages, Procedures for Compiling, Controlling, and Evaluating the Implementation of Regional Development Plans Which is of 3 classifications of development planning and budgeting cycles, namely participatory zones, technocratic zones and political zones. The participation zone that allows the involvement of many parties, especially the community, then the technocratic/bureaucratic zone at the government level in this case the regional head and the agencies below him, as well as the political zone which is a "battle of interests" involving DPRD members (Wicaksono, 2016).

*Address correspondence to this author at the Department of Health Administration and Policy, Faculty of Public Health, Hasanuddin University, Indonesia; E-mail: indar.sh@gmail.com
The classification of the cycle indicates that the legislator is one of the most instrumental in formulating the direction of development policies in an area, especially in terms of health planning. This is also confirmed in Article 42, Local Government Law No. 23 of 2004 which states that: (1) DPRD has the task and authority to form regional regulations which are discussed with regional heads for mutual approval. (2) The DPRD discusses and approves the draft regional regulation on APBD together with the Regional Head.

Of course, in carrying out their duties, the biggest challenge for legislators is the issue of health policy and the health planning process, not everything goes according to expectations. Especially in the regions, health budget allocations tend to be minimal, the realization of health programs that are not running, HR issues that are closely related to the interests of elites, overlapping or neglected health planning and evaluation are health political issues that are closely related to policy makers in health planning (Arianti, 2017).

Research by Bambang (2014) in the analysis of legislative and executive behavior towards health planning in Langsa City shows that the lack of knowledge and attitudes and the magnitude of the interest of each commission member in the DPRD makes the health budget allocation below $10 \%$ or around $5.8 \%$. Furthermore, Fitriyani (2016) explained in her research that this situation was caused by the weakness of health planning as a result of the lack of advocacy by the health department in planning health programs, namely the striking difference between the proposed program and the program that was approved 
and realized by decision makers, stakeholders and stakeholders. legislators as one of the mandate holders in the welfare of the community in their area.

Based on the background of the problem above, the researchers are interested in conducting research and studies on Legislator Behavior Analysis in Health Planning in South Sulawesi Province in 2021.

\section{MATERIAL AND METHOD}

This research is a qualitative research conducted in natural conditions (natural setting) so that the results of this study are more related to the interpretation of what is found in the field. This research was carried out at the Makassar City DPRD Office and Bantaeng Regency. intentional or snowball sampling, there were 8 informants. In this study the data sources were selected, and prioritized the emic perspective, which means that the informants' views are concerned, namely primary and secondary data. The data analysis of this study used content analysis.

\section{RESULTS}

This research is a qualitative research that aims to analyze the behavior of legislators in health planning in South Sulawesi Province in 2021. This research was carried out in the DPRD of Makassar City and Bantaeng Regency by looking at aspects of knowledge, attitudes, perceptions, actions and interests of legislators in the health planning process. This research was conducted from May to July 2021. The following is a presentation of research data.

\section{Characteristic of Information}

The characteristics of informants involved in research on the behavior of legislators in health planning in South Sulawesi Province in 2021 are as follows:

\section{Knowledge}

The following are excerpts from interviews conducted by researchers:

"..So the planning is internal to them... The related agencies, for example the health department, make plans for the health sector, so they prepare the data, and the priorities will be compiled later, then the finished program will be deposited in the form of a work plan... That's what will be discussed later... The General Policy of Regional Revenue and Expenditure Budget (KUA) discussion in RPRA by the committee members, then enters the first plenary stage and then enters the 2nd plenary session for ratification." (AWT,51 Years)

"No, because in the field of health, we are here at eee... this legislature has the name of equipment, indeed, it is divided into commissions. Commission $A$, commission $B$, commission $C$, so it just so happens that what is related to health data is not in my commission, it is in commission C. But the question of the data must have been well-available."

"...We usually look at health planning from the needs that exist in the community and based on data from the health office then it is realized at a meeting with the executive to decide what can be acceded in a meeting for health problems in Bantaeng" (HA, 42 Tahun)

Table 1: Characteristic of Research Informan

\begin{tabular}{|c|c|c|c|c|c|}
\hline No & Information Code & Ade (Year) & Position/ Commission & Education & Region \\
\hline \hline 1 & RT & 38 & Member of Commission A & S1 & Makassar City \\
\hline 2 & AWT & 51 & Chairman of Commission D (Budget Agency) & Makassar City \\
\hline 3 & AA & 37 & Chairman of Commission i C (Budget Agency) & D3 & District of . Bantaeng \\
\hline 4 & H & 38 & Chairman of RPRA & S1 & District of Bantaeng \\
\hline 5 & MAB & 41 & Chairman of Commission III & D3 & District of Bantaeng \\
\hline 6 & HA & 42 & Member of Commission III & S1 & District of . Bantaeng \\
\hline 7 & AU & 50 & Chairman of Commission II (Budget Agency) & S1 & District of Bantaeng \\
\hline 8 & MII & 28 & Member of Commission I &
\end{tabular}

Source: Primer Data, 2021

RPRA = Regional People's Representative Assembly 
"Yes, if we are in the RPRA, the plan is the city government, the city government submits it to the RPRA, we are only a budgeting function, and give suggestions if they really want to accept it" (RT, 38 years)

Informants' knowledge of the stages and processes of health planning does not seem to understand much and it can be interpreted that the informants' knowledge is still in the sufficient category.

\section{Attitude}

From the results of in-depth interviews with informants, the responses are based on the attitudes of legislators about health planning in South Sulawesi Province:

\begin{abstract}
"Eee... basically, the point is that we are here, because we represent many people, whatever it is. Let alone from the health office, but because this is the health department in particular, whatever it is if that is the output, the income is all good for the community, positive, we will definitely support it, yes." (HA, 42 Years)

"What is being carried out, which is called the Makassar recovery, we see as good, depending on the implementation. But what has been planned, I read it very well. So we give the city government time to implement and I am sure that the mayor can control it all."(RT , 38 years)
\end{abstract}

Furthermore, several informants explained the response given, which was to immediately see whether the program offered was really a priority for health problems, by comparing the data and rationalizing the data against the program budget.

"When, for example, there is a program that health issues want to carry out, eee.. of course we see eee.. the output of the activity itself, what kind of impact does it have on the community, when for example it is feasible for us to budget, we budget it. When, for example, it is not suitable for the benefit of the community, we will cross it out, like that. Depends on the utilization" $(\mathrm{H}, 38$ Years old $)$

"Eee... we study first, the program. Is it really the program launched by the local government that really directly affects the community, this goal is short-term, longterm, we will continue to discuss it with the commission's friends."(MII, 28 years old)

The response based on the attitude of the legislators regarding health planning in South Sulawesi Province strongly supports the program proposed by the government. Even so, the legislators continue to rationalize the data on the program so that the budget given is truly in accordance with what is needed and the programs included are truly in accordance with priorities public health problems.

\section{Perception}

From the results of in-depth interviews with informants, the perceptions of legislators about health planning in South Sulawesi Province:

"So we in the DPR are not planning, that's the role of the government, that's why in the city government there is an Local Government Work Plan (RKPD)

"...So we are together with them, we survey which ones are worthy, which ones are not. So, indeed, we are doing the intervention, we are maximizing it. Especially in the procurement of priority drugs, it is clear that they have analyzed it as early as possible, as far as possible. But we still enter proportionally, according to our budgetary rights. Our rationalization and agreement, and not in an authoritarian way, not voluntarily.... we continue to discuss, we put forward it is democratic between our partners" (MAB, 41 years old)

"eee... at the health department, it was budgeted for example one million, apparently because of the pandemic, more than that was needed, in the past, for example, the price of masks was only one thousand, two thousand, apparently after the pandemic they cost five thousand, which was budgeted less. Yes, this is where our job is for DPR, how do we support Banggar so that special funds are given or funds are added, like that. So that the result is good, right, like that. (HA,42 Years old)

The results of in-depth interviews with the informants regarding the legislator's perception of 
health planning in the stages it was found that the informants considered the executor who had the most role in health planning regarding the provision of data, program determination, and goals, the legislator was only at the assessment level.

\section{Action}

From the results of in-depth interviews with informants, the actions of legislators regarding health planning in the District of South Sulawesi Province:

"Eee... when it comes to interventions related to planning, I think like this, eee... the one who knows best about the situation, conditions and what to do is from the health department. So we are here by nature, we only support in general, but for intervention that is too deep, it is not. Because we give trust. They graduated from health, they already eee....." (HA, 42 Years old)

"......So we have to be responsible, but the role to regulate which is separately carried out by legislators has not yet been regulated so far as I have seen for that, but the supporters are still with the relevant agencies. There is no direct touch to health planning, supervision is there..." $(\mathrm{H}, 38$ years old $)$

"After The General Policy of Regional Revenue and Expenditure Budget (KUA) and Priority and Temporary Budget Ceiling (PPAS) enter, they will be discussed in the Bangar Commission and then discussed further in a plenary session" (AA, 37 years old)

"... in the budgeting process, at the end of the year we discuss the APBD, we really, really... intervene in the budget, the budget for health. We sit down together, discuss whether this is indeed compatible, we have done a field survey, we match the numbers, don't let there be other places that need it.....and budgetary intervention is very feminine, moreover supervision, supervision of intervention depends on aspirations the community and our surveys go to the public, what are the complaints, what are the obstacles often faced by the community regarding health services and if we do encounter that, we need to record complaints........ ." (MAB, 41 Years)

Actions by informants are understood as executive duties. Informants are able to explain what is part of the health planning but is not accompanied by the actions taken in each of these parts.

\section{Interest}

All informants generally stated that interests cannot be separated from all the activities of legislators, but when compared to the interests of the community, the priority of personal interests is at the bottom, this can be seen from the results of interviews with informants as follows:

"If there is no personal interest, but for the public interest, that's for sure. That is also a responsibility and it is an oath promise by DPRD members that they will remain responsible to the community...." $(\mathrm{H}, 38$ Years)

"I think that interests cannot be separated from the world of politics. But, again, we put the public interest first, frankly... why do we work, we are given the mandate by the people, if we prioritize our personal interests....." (MAB, 41 Years Old)

"I think that interests cannot be separated from the world of politics. But, again, we put the public interest first, frankly... why do we work, we are given the mandate by the people, if we prioritize our personal interests....." (MAB, 41 Years Old)

"There is, there is very much. If the priority is, the priority scale is not for the benefit of the community."(AU, 50 Years)

From the results of interviews, there are still some informants who think that individual interests exist and group interests in this case constituents and political parties as vehicles to become members of the people's representative council in the regions so that they are still part of determining policies, including in the health sector program.

\section{DISCUSSION}

Knowledge is very closely related to education, someone with higher education, then that person will 
have wider knowledge (Rahman, 2017). Informants' knowledge of the planning stage in South Sulawesi Province is still in the category of not knowing the planning stages systematically starting from the need for data as initial material to the evaluation stage in the community. Judging from the aspects used to assess the knowledge of legislators, education does not have a significant influence on the knowledge of informants, this is influenced by the tenure of the informant, where there are informants who have lower education but have a longer tenure so that they know the stages health planning is better than those who have a higher level of education but have not worked for a period of time. This result is in line with Bakri's research (2017) which says that knowledge can be obtained from experience both from personal experience and from the experiences of others.

The attitude of legislators towards health planning in South Sulawesi Province shows support for the government, especially the response of the Makassar City government in controlling the Covid-19 pandemic. legislators on health planning indicate satisfaction with the performance of local governments, but do not neglect the duties and functions of legislators in terms of supervision and budgeting, where the proposed program is not immediately accepted by legislators. Legislators continue to rationalize data by presenting comparative data from credible agencies and in accordance with the proposed program so that public health problems can actually be resolved by looking at the priority problems obtained. (Mallongi et al., 2017; Awal et al., 2017: Posmaningsih et al., 2018)

The perception given also indicates a lack of understanding of legislators regarding the correct and appropriate health planning process. Informants only follow up on program proposals according to procedures. This is in line with research conducted by, Parmedy (2011) that legislative perceptions are sometimes very standard on existing procedures, do not innovate or develop so they tend not to develop.

In line with this, the view of the informants in terms of action on health planning is considered by researchers to be still at the normative level. Health planning by legislators is very relative in its realization. This is also influenced by the limited space for legislators who only have the authority to carry out oversight and budgeting functions, moreover the budget that can be allocated is also limited so that legislators need to consider carefully the priority health problems in Bantaeng Regency that need to be given more budget. This is in line with research conducted by (Ilham, 2013) which states that the attitude of legislators in terms of making decisions regarding programs is that as policy makers, they are not involved in the elements of the process, let alone initial observations in the community.

Health planning in the legislature is certainly inseparable from the interests brought by each legislator, this is also in accordance with the cycle described in PP 08 of 2008 concerning Stages, Procedures for Compiling, Controlling, and Evaluating the Implementation of Regional Development Plans where DPRD into the "political" zone that is thick with interests (Rozidetano, 2016). It is known that the informant stated something more normative that there was a problem of interest, namely the interests of the community. The rest stated that there must be interest, both personal and group, which is also the goal in the legislative process in the DPRD in all aspects. The realization of the program tends to see the interests in it, such as personal interests, in realizing the amount of the health budget or health program. (Nur et al., 2016; Russeng et al., 2020)

The interest in the realization is how the actors are able to negotiate, this is one of the determining factors in the midst of the many problems that must be maximally financed while the funds they have are limited in this situation the actors will do bargaining by utilizing their power base to strengthen their bargaining power to the stage of making decision. Such a situation is often termed a brokery phenomenon where the substantive interests of each actor involved turn out to be slipping the hidden interests of the actors themselves or orders by orders of external actors (Ardianto et al., 2020). Overall, the informants are interested.

\section{CONCLUSION}

Based on the results of in-depth interviews conducted at the Regional People's Representative Assembly (DPRD) Makassar City and Regional People's Representative Assembly (DPRD_Bantaeng Regency, it was concluded that the indicators of knowledge, attitudes, perceptions and actions of legislators on health planning in Bantaeng Regency were in the poor category. On the other hand, there were interests brought by legislators in health planning in particular in determining the program budget, but in the end it is for the benefit of the community in this case to improve the health status of the community. 


\section{RECOMMENDATION}

Increasing the knowledge and insight of regional legislators, especially in the health sector as a starting point for the progress of a region through education, training, seminars and workshops on public health. It is recommended to increase the understanding of members of legislators and budget bodies about work programs in the health sector through education, training, seminars and workshops

The need for increasing legislators' reactions to the proper stages of health planning. There is support, great participation from all elements of the region, both the government and the community to work together in synergy with legislators in terms of prioritizing public health issues.

\section{REFERENCES}

Ardianto, Prisanto, G. F., Irwansyah, I., Ernungtyas, N. F., \& Hidayanto, S. (2020). Praktik Lobi dan Negosiasi oleh Legislator Sebagai Bentuk Komunikasi Politik. Komuniti : Jurnal Komunikasi Dan Teknologi Informasi, 12(1), 25-39. https://doi.org/10.23917/komuniti.v12i1.10009

Ariyanti, E. (2017). Pengaruh Pengetahuan Dewan Tentang Anggaran Terhadap Pengawasan Keuangan Daerah (APBD) dengan Political Background, akuntabilitas Public dan Transparansi Kebijakan Public Sebagai Variabel Pemoderasi (Study Empiris Pada DPRD Kab.Pelalawan). Jom Fakultas Ekonomi, 4, 1295-1309.

Bakri. (2017). Analisis Stakeholder dalam Perencanaan Kesehatan Kabupaten Wonogiri.

Fitriany, M., Farouk, H., \& Taqwa, R. (2016). Perilaku Masyarakat Dalam Pengelolaan Kesehatan Lingkungan (Studi di Desa Segiguk sebagai Salah Satu Desa Penyangga Kawasan Hutan Suaka Margasatwa Gunung Raya Ogan Komering Ulu Selatan). Jurnal Penelitian Sains, 18(1), 168118.

Hamida, R. P. (2016). Dinamika Penyusunan ANggaran Daerah: Kasus Proses Penetapan Program dan Alokasi Anggaran Belanja Daerah di Kabupaten Sleman. Jurnal Penelitian Politik, 07(1). https://doi.org/10.1016/j.psychres.2014.11.019

Ilham, A. (2013). Hubungan Legilslatif dalam Proses Pembuatan Perda APBD Tahun 2013 Provinsi Sulsel. Universitas Hasanuddin.

Irawan, B. (2014). Analisis Perilaku Legislatif dan Eksekutif Dalam Perencanaan Kesehatan Di Kota Langsa Sumatra Utara. Universitas Sumatera Utara.
Mallongi, A., Daud, A., Ishak, H., La Ane, R., Birawida, A.B., Ibrahim, E., Selomo, M., Rahman, S.A. (2017). Clean water treatment technology with an up-flow slow sand filtration system from a well water source in the tallo district of Makassar. Journal of Environmental Science and Technology, Volume 10, Issue 1, Pages 44-48.

https://doi.org/10.3923/jest.2017.44.48

Marhaeni, D. (2008). Intervensi Politik dalam Pengawasan dan Penganggaran Departemen Kesehatan 2006-2007. Jurnal Manajemen Pelayanan Kesehatan, 11, 173-178. Retrieved from ejournal.unsrat.ac.id

Muhammad Awal, Ridwan Amiruddin, Sukri Palutturi and Anwar Mallongi, (2017) Relationships Between Lifestyle Models with Stroke Occurrence in South Sulawesi, Indonesia. Asian Journal of Epidemiology, 10: 83-88. https://doi.org/10.3923/aje.2017.83.88

Pallutturi, S. (2015). Politik Kesehatan. Yogyakarta, Pustaka Pelajar.

Parmedy. (2011). Analisis Penyusunan Dan Penetapan Anggaran APBD Dinas Kesehatan Kabupaten Nunukan Tahun 2011. Makassar: Universitas Hasanuddin.

Posmaningsih, D.A., Aryasih, G.A.M., Hadi, M.C., Marwati, N.M., Mallongi, A.(2018). The influence of media booklet in behavior change of waste management in elementary school students, South Denpasar, Bali., Indian Journal of Public Health Research and Development. Volume 9, Issue 8, Pages 1506-1511 https://doi.org/10.5958/0976-5506.2018.00946.4

PP 08 Tahun 2008 tentang Tahapan, Tata Cara Penyusunan Penyusunan, Pengendalian, dan Evaluasi Pelaksanaan Rencana Pembangunan Daerah

Rosmala Nur and Anwar Mallongi, (2016). Impact of Violence on Health Reproduction Among Wives in Donggala. Pakistan Journal of Nutrition, 15: 980-988. https://doi.org/10.3923/pjn.2016.980.988

Russeng, S. S., Saleh, L. M., Awaluddin, M., \& Mallongi, A. (2020) Intervention model for barotrauma diseases to improve health and safety diving behaviors in traditional fishermen in small islands in Makassar, Indonesia. Sys Rev Pharm, 11(9), 597-600.

Rahman, N. (2017). Kelembagaan Legislasi Peta Jalan Politik Menuju Penguatan. Fahmis Pustaka.

Turnip, A. D., Suntono, I., \& Nurmalisa, Y. (2016). Persepsi Masyarakat Terhadap Peran Partai Politik Dalam Pemilihan Kepala Daerah di Desa Branti Kecamatan Natar Kabupaten Lampung Selatan Tahun 2015. Jurnal Kultur Demokrasi, $4(3)$. https://doi.org/10.15408/jch.v4i1.2578

Wicaksono, B. (2016). Konsolidasi kepentingan eksekutif dan legislatif dalam Penganggaran daerah di Kabupaten Situbondo. Jurnal transformative.

Undang-Undang Nomor 23 Tahun 2014 tentang Pemerintah Daerah.

https://doi.org/10.6000/1929-4409.2021.10.179

(C) 2021 Indar et al.; Licensee Lifescience Global.

This is an open access article licensed under the terms of the Creative Commons Attribution License (http://creativecommons.org/licenses/by/4.0/) which permits unrestricted use, distribution and reproduction in any medium, provided the work is properly cited. 